\title{
THE CLASSIFICATION OF LAKE SEDIMENTS BASED ON COLOR DETERMINATIONS
}

\author{
LeENA SOINIEMI
}

\begin{abstract}
Soiniemi, Leena 1972: The classification of lake sediments based on color determinations. Bull Geol. Soc. Finland 44, 9-11.

Ten lake sediment cores from southern Finland has been studied by color method based upon »Methuen Handbook of Color» (Kornerup \& Wanscher, 1961) for description and classification of sediments.

Leena Soiniemi, Department of Geology and Palaeontology, University of Helsinki, 00170 Helsinki 17, Finland.
\end{abstract}

\section{Introduction}

The classifications of lake sediments are usually based upon microscopic examination (Lundqvist, 1924, 1926, 1927 and Naumann, 1921, 1931) or chemical determinations (Hansen, $1959 \mathrm{a}$ and b, 1961). At the end of the 1940 's some attempts were made in Finland to make the definitions and classifications of sediments uniform (Aaltonen et al., 1949).

The color of the sediments is mentioned in almost all classifications. As it is, however, very inexact to explain color merely by words, it is necessary to use color models, e.g. "Methuen Handbook of Color» (Kornerup \& Wanscher, 1961) and »Munsell Book of Color» (Munsell, 1960). For example, Papadakis (1969) and Dimbleby (1962) have made use of colors in their studies concerning podsol profiles.
The objective of this study was to find out whether the lake sediments consistently change color as the quantity and quality of organic matter vary, and also whether the color tabulation founded upon "Methuen Handbook of Color» (Kornerup \& Wanscher, 1961) can be used for the description and classification of sediments.

Most of the samples in this study come from sediment cores taken by Saarnisto in an earlier survey published (Saarnisto, 1970) (See fig. 22, 24, 27, 28, 29, 30 and 35 in Saarnisto, 1970). These sediments come from the Saimaa lake complex. The remaining cores are collected from three lakes in south-western Finland, Koskuenjärvi (Urajärvi, $6100.06,250.47,106$ m), Uudenkylänlampi (Salkola, 6 723.60, 498.14, $130.7 \mathrm{~m}$ ) and Keisarlampi (Porras, 6 738.94, 499.62, 119.4 $\mathrm{m})$.

$2 \quad 14993-71$ 


\section{Methods}

The content of organic matter is shown as loss-on-ignition. For this purpose the sample was first dried in an incubator at $110^{\circ} \mathrm{C}$, after which it was weighed and burnt for two hours in an owen at $550^{\circ} \mathrm{C}$. Finally, it was weighed once more. The loss-on-ignition is given as percentages.

The color models were prepared as follows: part of the sediment that was dried in the incubator was powdered in an agatemortar and strewn down on a white card in an area about $1 \times 2 \mathrm{~cm}$, which was first covered by colorless gum. After the sample had dried, extra powder was shaken off.

\section{Results}

The color cards were compared with the models in » Methuen Handbook of Color» (Kornerup \& Wanscher, 1961) and every sample obtained a letter and number code of its own. The loss-on-ignition values for corresponding depths were observed which made it possible to calculate the variation of the values and find out the limit values where the color changes were noticed (Table 1).

TABLE 1

Suggestion to classification based upon colors

\begin{tabular}{|c|c|c|c|}
\hline Matter & $\begin{array}{l}\text { Loss-on- } \\
\text { ignition }\end{array}$ & \multicolumn{2}{|c|}{ Color } \\
\hline Dy $\ldots \ldots \ldots$ & $58-72 \%$ & 5 F 4 & sepia brown \\
\hline \multirow[t]{4}{*}{ Mud $\ldots \ldots$. } & $34-55 \%$ & 5 E 3 & drap grey \\
\hline & $15-35 \%$ & $5 \mathrm{D} 3$ & nougat \\
\hline & $38-53 \%$ & $4 \mathrm{~F} 2-3$ & smoke brown \\
\hline & $16-31 \%$ & 4 E $2-3$ & olive grey \\
\hline Clay-Mud ... & $6-15 \%$ & 4 D $2-3$ & $\begin{array}{l}\text { brownish } \\
\text { grey }\end{array}$ \\
\hline Mud-Clay ... & $2-6 \%$ & $3 \mathrm{D} 2$ & $\begin{array}{l}\text { yellowish } \\
\text { grey }\end{array}$ \\
\hline Clay ...... & $\begin{array}{c}\text { less than } \\
2 \%\end{array}$ & $3 \mathrm{C} 2$ & smoke grey \\
\hline
\end{tabular}

The results of these observations show that sediments can be classified by the help of the color method, if those points that can be defined by the aid of the color changes are chosen as limit values. The sediments are classified as follows (Table 1):

Sediments of the color 5 F 4 (sepia brown) are called DY. The contents of the organic matter in these sediments varied between 58 and $72 \%$.

Light brown sediments 5 D 3 (nougat) and 5 E 3 (drap grey) are called MUD. The former had on loss-on ignition varying between 15-33 $\%$, the latter between $34-55 \%$. Also greenbrown sediments 4 E 2-3 (olive grey) corresponding to the first-mentioned and sediments of the color 4 F 2-3 (smoke brown) are called mud, because the percentage of organic matter for the latter varied between approximately the same limits as for the first-mentioned sediments.

The group of mud in this study is made up of muds with extremely varying origin. More precise definitions have not been attempted.

Sediment of the color 4 D 2-3 (brownish grey) with a content of organic matter of 6$15 \%$ is called CLAY-MUD.

The color of MUD-CLAY is 3 D 2 (yellowish grey), and the loss-on-ignition values of this kind of sediment varied between 2 and $6 \%$.

Sediment of the color 3 C 2 (smoke grey) with less than $2 \%$ organic matter and a grain size of less than $0.002 \mathrm{~mm}$ is called CLAY.

The distribution of the sediments in the color tables of »Methuen Handbook of Color» is presented in Table 2.

In earlier literature the limit of organic matter is fixed at $30 \%$, when clay-mud changes into mud (Soveri, 1964). In this study this limit is placed at $15 \%$. Thus the percentage of organic matter in clay-mud is $6-15 \%$ and in mud 15$50 \%$. Above the changing point of these two sediments there may still be comparatively much mineral matter in the mud, but as the color of 
TABLE 2

The distribution of the sediments and their color in the color chart (Kornerup \& Wanscher, 1961). The numbers 3,4 and 5 to the left are the numbers of the plates. The following vertical number show the increasing density, the smallest number showing the greatest density. The horizontal letters show the increasing degree of shadow from left to right.

3

\begin{tabular}{|c|c|c|}
\hline & C & $\mathrm{D}$ \\
\hline 2 & Clay & Mud-Clay \\
\hline
\end{tabular}

4

3

2

D

E

F

\begin{tabular}{|l|l|}
\hline Clay-Mud & Mud \\
\hline
\end{tabular}

5

\begin{tabular}{|c|c|c|}
\hline \multirow[t]{2}{*}{ D } & \multirow[t]{2}{*}{$\mathrm{E}$} & $\mathrm{F}$ \\
\hline & & Dy \\
\hline & & \\
\hline
\end{tabular}

the mud is the same at the level of organic matter of $15 \%$ and $50 \%$, the limit value has been lowered to $15 \%$. The other limits mentioned in earlier literature are the same as those based on the color changes: the percentage of organic matter in clay is less than $2 \%$ and in mud-clay between 2 and $6 \%$.

Acknowledgements - The author wishes to express her gratitude to Professor Joakim Donner for support and advice during the work.

She wishes to thank Dr Matti Saarnisto for giving his material from the Saimaa district and Dr Hannu Hyvärinen and Dr Pentti Alhonen for assistance during the field work.

She also thanks Miss Elisabeth Heikkilä, who kindly translated the text.

\section{REFERENCES}

Aaltonen, V et al., 1949: Maaperäsanaston ja maalajien luokituksen tarkistus. - Maataloustieteellinen aikakirja 21.

Dimbleby, G. W., 1962: The Development of British Heathlands and their Soils. - Oxford.

HANSEN, K., 1959 a: The terms Gyttja and Dy. - Hydrobiologica Vol. XIII.

- 1959 b: Sediments from danish lakes. - Journal of Sedimentary Petrology 29.

- 1961: Lake types and Lake sediments. - Verh. Internat, Verein. Limnol. XIV.

Kornerup, A. \& Wanscher, J. H., 1961: Methuen Handbook of Color. - Copenhagen.

Lundqvist, G., 1924: Sedimentationstyper i insjöarna. En orientering. - Geol. Fören. Förh. Bd. 46.

- 1926: En metod för mikroskopiska sedimentanalyser. - Geol. Fören. Förh. Bd. 48.
- 1927: Bodenablagerungen der Seen. - Binnengewässer 2 .

Munsell, A. H., 1960: Munsell Book of Color. - Baltimore.

Naumann, E., 1921: Die Bodenablagerungen des Süsswassers. Eine einführende Uebersicht. - Archiv. f. Hydrobiologie, 13.

- 1931: Limnologische Terminologie in Abderhalden. Handbuch d. biol. Arbeitsmetoden. Teil I.

PAPADAkis, J., 1969: Soils of the World. - Amsterdam, London, New York.

SAarnisto, M., 1970: The Late Weichselian and Flandrian History of the Saimaa Lake Complex. - Soc. Scient. Fennica Vol. 37.

Manuscript received, April 1, 1971. 